\title{
The role of Epstein-Barr virus infection in the development of autoimmune thyroid diseases
}

\author{
Rola infekcji wirusem Epstein-Barr'a w rozwoju autoimmunologicznych \\ chorób tarczycy
}

\author{
Andrea Janegova ${ }^{1}$, Pavol Janega ${ }^{1,2 *}$, Boris Rychly ${ }^{3}$, Kristina Kuracinova ${ }^{1}$, Pavel Babal ${ }^{1}$ \\ ${ }^{1}$ Department of Pathology, Faculty of Medicine, Comenius University, Bratislava, Slovak Republic \\ ${ }^{2}$ Institute of Normal and Pathological Physiology, Slovak Academy of Sciences, Bratislava, Slovak Republic \\ ${ }^{3}$ Cytopathos s.r.o., Bratislava, Slovak Republic
}

\begin{abstract}
Introduction: Autoimmune thyroid diseases, including Graves' and Hashimoto's thyroiditis, are the most frequent autoimmune disorders. Viral infection, including Epstein-Barr virus (EBV), is one of the most frequently considered environmental factors involved in autoimmunity. Its role in the development of AITD has not been confirmed so far.

Material and methods: Surgical specimens of Graves' and Hashimoto's diseases and nodular goitres were included in the study. The expression of EBV latent membrane protein 1 (LMP1) was analysed by immunohistochemistry, with the parallel detection of virus-encoded small nuclear non-polyadenylated RNAs (EBER) by in situ hybridisation.

Results: In none of the Graves' disease specimens but in 34.5\% of Hashimoto's thyroiditis cases the cytoplasmic expression of LMP1 was detected in follicular epithelial cells and in infiltrating lymphocytes. EBER nuclear expression was detected in 80.7\% of Hashimoto's thyroiditis cases and $62.5 \%$ of Graves' disease cases, with positive correlation between LMP1 and EBER positivity in all Hashimoto's thyroiditis LMP1-positive cases.

Conclusions: We assume that high prevalence of EBV infection in cases of Hashimoto's and Graves' diseases imply a potential aetiological role of EBV in autoimmune thyroiditis. The initiation of autoimmune thyroiditis could start with EBV latency type III infection of follicular epithelium characterised by LMP1 expression involving the production of inflammatory mediators leading to recruitment of lymphocytes. The EBV positivity of the infiltrating lymphocytes could be only the presentation of a carrier state, but in cases with EBER + / LMP1+ lymphocytes (transforming latent infection) it could represent a negative prognostic marker pointing to a higher risk of primary thyroid lymphoma development. (Endokrynol Pol 2015; 66 (2): 132-136)
\end{abstract}

Key words: Graves’ disease; Hashimoto thyroiditis; Epstein-Barr virus infections

\section{Streszczenie}

Wstęp: Autoimmunologiczne choroby taczycy, w tym zapalenia tarczycy Graves'a i Hashimoto, są najczęstszymi zaburzeniami autoimmunologicznymi. Infekcja wirusowa, w tym wirusem Epstein-Barr'a (EBV), jest jednym z najczęściej rozważanych czynników środowiskowych łączonych $z$ autoimmunologią. Jego rola w rozwoju autoimmunologicznyh chorób taczycy (AITD) nie została do tej pory potwierdzona. Materiały i metody: Zbadano chirurgicznie pobrane preparaty od chorych na chorobę Gravesa, chorobę Hashimoto i wole guzowate. Ekspresja latentnego białka błonowego 1 (LMP1) EBV była zanalizowana metodami immunohistochemicznymi, z równoczesnym wykrywaniem kodowanych wirusem, małych, jądrzastych, niespoliadenylowanych RNA (EBER) poprzez hybrydazcję in situ.

Wyniki: W żadnym z przypadków choroby Gravesa nie stwierdzono w komórkach pęcherzykowych i naciekających limfocytach ekspresji LMP1w cytoplazmie, ale wykryto ją w 34,5\% przypadkach choroby Hashimoto. Jądrowa ekspresja EBER została wykryta w 80,7\% przypadków zapalenia tarczycy Hashimoto i w 62,5\% choroby Gravesa. Zauważono również dodatnią korelację pomiędzy LMP1 i występowaniem EBER we wszystkich przypadkach choroby Hashimoto LMP1+.

Wnioski: Autorzy uwazają, że powszechne występowanie infekcji EBV w chorobach Hashimoto i Gravesa sugeruje potencjalną rolą etiologiczną EBV w rozwoju autoimmunologicznych zapaleń tarczycy. Zapoczątkowaniem autoimmunologicznych zapaleń tarczycy może być utajona infekcja EBV typu III, charakteryzująca się ekspresją LMP1 w komórkach pęcherzykowych i związana z produkcją mediatorów zapalnych prowadzącą do migracji limfocytów. Obecność EBV w naciekach limfocytarnych może być jedynie charakterystyczna dla nosiciela wirusa ale w przypadku obecności limfocytów EBER+/LMP1+ (przekształcajcych infekcję utajoną) może być negatywnym markerem prognostycznym wskazując podwyższone ryzyko rozwoju pierwotnego chłoniaka tarczycy. (Endokrynol Pol 2015; 66 (2): 132-136)

Słowa kluczowe: Choroba Gravesa; zapalenie tarczycy typu Hashimoto; infekcje wirusem Epsterin-Barra 


\section{Introduction}

Autoimmune thyroid diseases (AITD), including Graves' disease and Hashimoto's thyroiditis, afflict up to $10 \%$ of the world population [1]. Their aetiology remains unclear at present but it is generally believed that both genetic and environmental factors contribute to their development [2]. Viral infections are frequently cited as a major environmental factor involved in the pathogenesis of autoimmune processes.

The Epstein-Barr virus (EBV) is a double-stranded DNA virus, a member of the herpes virus family [3]. Approximately $95 \%$ of the world's adult population is infected during life and become lifelong carriers. Primary infection by EBV causes quite a different course of the disease depending on the age of the patient [4]. EBV infection is associated with the development of a variety of lymphoid and epithelial tumours and post-transplant lymphoproliferative disorders [5-7]. EBV infection is also known to be involved in the development of different autoimmune diseases. Several studies brought evidence for the connection of EBV infection and multiple sclerosis $[8,9]$ and even suggested a prognostic role of elevated anti-EBV antibody titres in MS development [10]. Toussirot et al. demonstrated serological differences in patients with systemic lupus erythematodes and rheumatoid arthritis in comparison to healthy controls, and confirmed the presence of viral DNA and RNA in disease targeted tissue in patients with rheumatoid arthritis and Sjögren syndrome [11]. AITDs have also been shown to be associated with a variety of infectious agents, including EBV [12]. Most of these data are only indirect epidemiological and serological indications [13] and they do not prove the pathogens causality. Considering the limited direct evidence, the present study focused on direct EBV detection in the thyroid tissue from patients with autoimmune thyroid gland diseases.

\section{Material and methods}

Archival formalin fixed in paraffin embedded specimens from therapeutic and diagnostic thyroidectomies, including the diagnosis of Hashimoto's thyroiditis $(\mathrm{n}=26)$, Graves' disease $(\mathrm{n}=8)$, and nodular goitres $(n=8)$ as controls, were used for analysis. The samples were evaluated and classified on the basis of published histopathological criteria [14].

\section{Immunohistochemistry}

For the immunohistochemical detection of EBV infected cells, antibodies against the viral latent membrane protein 1 (LMP1) were used. Two different primary antibodies were tested: monoclonal mouse anti-LMP protein (clone CS.1-4, Dako, Denmark) and monoclonal mouse anti-LMP Ab-1 protein (clone CS.1-4, Labvision, USA). Deparaffinisation was followed by seven minutes of proteinase K-induced epitope retrieval. Afterwards, the sections were incubated first with primary antibodies for 60 minutes at room temperature and then for 30 minutes with the secondary antibody (Envision, Dako, Denmark). Visualisation of the antigen site was achieved by 3, 3'-diaminobenzidine (Dako).

\section{In situ hybridisation}

The fluorescein-conjugated EBV Probe ISH Kit (Vector Laboratories, USA) was used for the detection of virus-encoded small nuclear non-polyadenylated RNAs (EBER) in the latently infected cells. The $5-\mu \mathrm{m}$ thick tissue sections were incubated with the probe for 2 hours at $37^{\circ} \mathrm{C}$, followed by 10 minutes incubation with blocking solution (rabbit serum diluted 1:5 in Tris buffered saline - TBS, containing 3\% bovine albumin) and 30 minutes incubation with rabbit anti-fluorescein secondary antibody conjugated with alkaline phosphatase diluted 1:200 in TBS. The alkaline phosphatase activity was visualised by overnight incubation with the enzyme substrate diluted 1:50 in substrate buffer with the inhibitor of endogenic phosphatase activity (levamisole hydrochloride) diluted 1:1000. The slides were counterstained with nuclear red.

Samples, incubated without addition of primary antibody or the EBV probe, were used as negative controls. The expression of both viral LMP1 and EBER were evaluated by optical microscope. Only cytoplasmic LMP1 expression and nuclear EBER expression were considered positive.

\section{Results}

Immunohistochemical EBV positivity was demonstrated only in samples of Hashimoto's thyroiditis. In 8 of $26(34.5 \%)$ Hashimoto's thyroiditis cases there was cytoplasmic expression of viral latent membrane protein 1 (LMP1) in follicular epithelial cells and in infiltrating lymphocytes (Fig. 1). Graves' disease specimens and control goitres were negative for LMP1. Antibodies from both manufacturers gave comparable intensity of positivity and expression pattern of LMP1; negative control samples showed no positivity.

The detection of EBV-positive cells with the use of in situ hybridisation method (detection of EBER) showed nuclear expression in 21 of 24 Hashimoto's thyroiditis cases $(80.7 \%$ ) and in 5 of 8 Graves' disease cases (62.5\%). Samples of Hashimoto's thyroiditis demonstrated focal to diffuse positivity, mainly of infiltrating lymphocytes. In the areas with lymphatic follicles predominantly the mantle zone and interfollicular lymphocytes were 


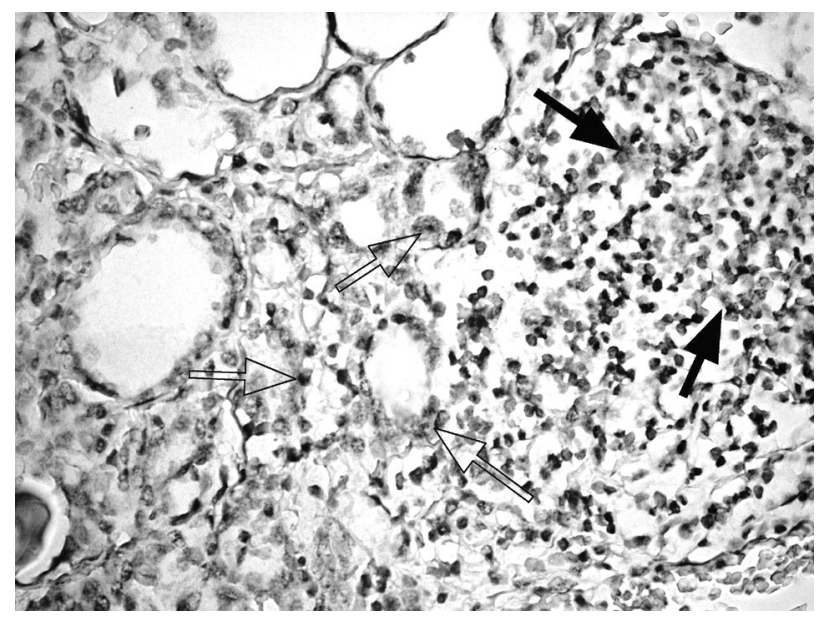

Figure 1. LMP1 expression in Hashimoto's thyroiditis. Immunohistochemical reaction with cytoplasmic latent membrane protein 1 (LMP1) positivity showed EBV presence in follicular epithelial cells (open arrow) and in infiltrating lymphocytes (arrow). Avidin-biotin-peroxidase, diaminobenzidine, $400 \times$

Rycina 1. Ekspesja LMP1 w zapaleniu tarczycy Hashimoto. Reakcja immunohistochemiczna z cytoplazmatycznym latentym białkiem błonowym 1 (LMP1) uwidocznita obecność EBV w komórkach pęcherzykowych (pusta strzałka) i w naciekajacych limfocytach (strzatka). Awidyna-biotyna-peroksydaza, diaminobenzydyna, 400×

positive (Fig. 2). In three cases positivity of epithelial cells predominated. Samples of Graves' disease demonstrated EBER expression predominantly in follicular epithelial cells (Fig. 3). All negative control samples lacked EBER positivity.

Positive correlation was found between LMP1 immunohistochemical positivity and EBER in situ hybridisation results in all eight Hashimoto's thyroiditis LMP1 positive cases.

\section{Discussion}

The causative role of infectious agents represents an attractive hypothesis in the development of autoimmune diseases. Indirect epidemiological and serological data indicate the involvement of infectious agents in the initiation and/or progression of autoimmune processes [13].

Epstein-Barr virus is a widespread human herpes virus mostly causing latent asymptomatic infection; however, it is also associated with several neoplastic diseases. There is also increasing evidence of its connection with autoimmune diseases. According to Toussirot [11], EBV fulfils all criteria for a causal factor of autoimmunity, including the worldwide prevalence, the autoimmunity preceding infection, and the capability to modify the host's immune response. Despite of lack of clear confirmation of an etiopathogenic role of EBV

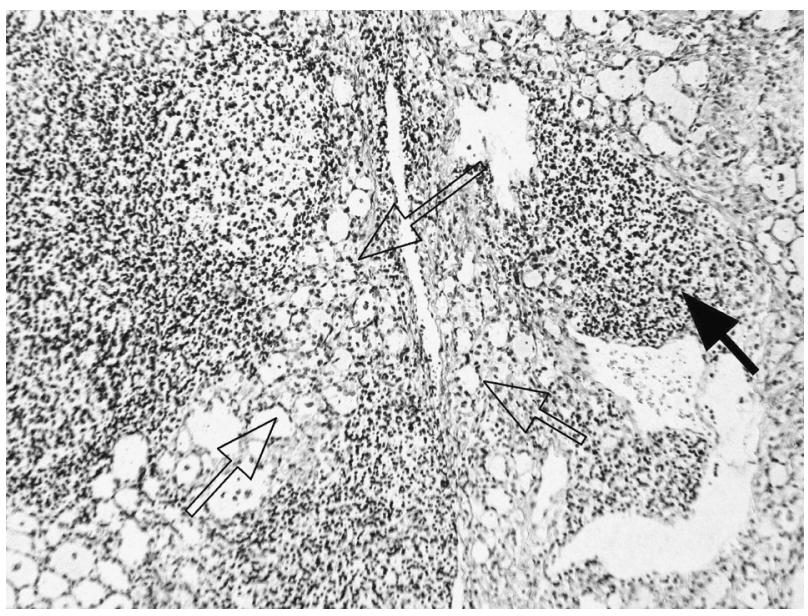

Figure 2. EBV in lymphocytic infiltration in Hashimoto's thyroiditis. In situ hybridisation reaction with virus-encoded small nuclear non-polyadenylated RNAs (EBER) showed EBV presence in the nuclei of infiltrating lymphocytes (arrow) and in nuclei of follicular cells (open arrow). EBER, 150×

Rycina 2. EBV w limfatycznej infiltracji w zapaleniu tarczycy Haschimoto. Reakcja hybrydyzacji in situ z kodowanymi wirusowymi, małymi jądrzastym, niespoliadenylowanymi RNA (EBER) potwierdziło obecność EBV w jądrach infiltrujących limfocyty (strzałka) $i$ w jadrach komórek ziarnistych (pusta strzatka). EBER, $150 \times$

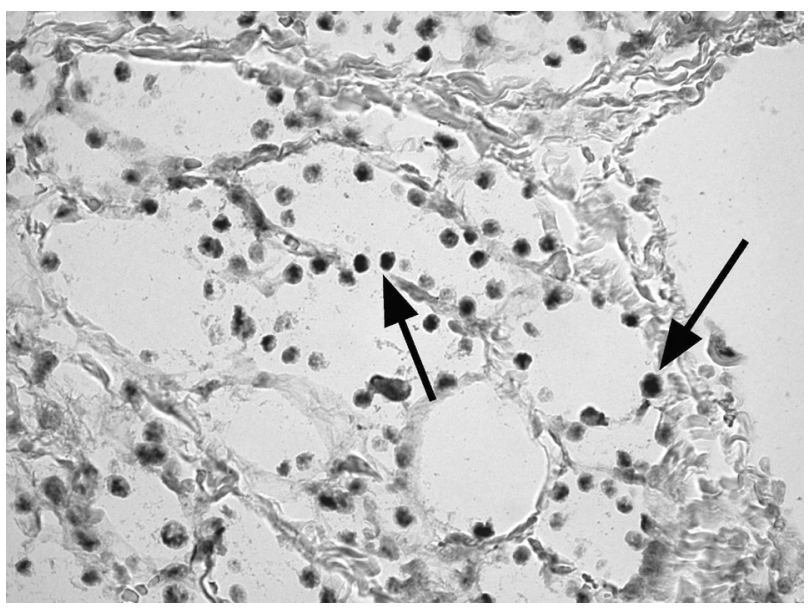

Figure 3. EBV in Grave's thyroiditis. In situ hybridisation reaction with virus-encoded small nuclear non-polyadenylated RNAs (EBER) showed EBV presence in the nuclei of follicular cells (arrow). EBER, $400 \times$

Rycina 3. EBV w zapaleniu tarczycy Gravesa. Reakcja hybrydyzacji in situ z kodowanymi wirusowymi, małymi, jądrzastymi, niespoliadenylowanymi RNA (EBER) potwierdzita obecność EBV w jądrach komórek ziarnistych (strzatka). EBER, 400×

in autoimmune processes, some studies have already proven the presence of viral genes in disease affected tissues and organs $[11,15,16]$. 
Our study demonstrated the presence of EBV in the thyroid gland tissues affected by autoimmune thyroiditis. Evaluation of viral nuclear RNA (EBER) positivity pointed to a high prevalence of EBV in cases of Hashimito's thyroiditis (80.7\%) as well as in Grave's disease $(62.5 \%)$. On the contrary, none of the control goitres demonstrated EBER expression. The question is whether this high occurrence of EBV in thyroid gland samples is associated directly with autoimmune disease development or if it is the result of the high EBV carrier rate in the population. The absence of EBV in all control goitres observed in our study favours the first possibility. An analogical attempt to map the herpes simplex 1 and 2, CMV and human herpes virus type 6 and 7 infection in tissue samples of AITDs did not provide any conclusive connections [16].

The main target cells for EBV are B lymphocytes, but the virus can infect also $\mathrm{T}$ lymphocytes and epithelial cells [17]. The present study demonstrates the expression of EBV-associated products in infiltrating lymphocytes in Hashimoto's thyroiditis and in thyroid follicular cells in cases of Hashimoto's thyroiditis and Grave's disease.

EBV infects cells in latent or lytic forms. Latently infected cells generally show different gene expression patterns. In latency type I, or resting state, only EBV nuclear antigen 1 (EBNA-1) and two small polyadenylated nuclear RNAs (EBER 1 and 2) are expressed, as typically found in Burkitt's lymphoma cells. In latency type II additional expression of three latent membrane proteins, LMP-1, LMP-2A, and LMP-2B is observed, as described in Hodgkin's disease and the nasopharyngeal carcinoma. Latency type III (continuously proliferating state) is seen in lymphoproliferative diseases arising in EBV-transformed lymphoblastoid cells in immunocompromised individuals. In this group all six EBNAs, all three LMPs, and the two EBERs are expressed. Latency type IV is found in patients with infectious mononucleosis and with post-transplant lymphoproliferative disease [17].

The immunohistochemically detected latent membrane protein traced in 8 of 24 Hashimoto's thyroiditis cases is associated with latent viral infection and is characteristic for latency type II and III, but not for latency type I [18]. In contrast to LMP1, EBER, detected in 21 of 24 Hashimoto's thyroiditis and in 5 of 8 cases of Graves' disease, is expressed in all types of latent EBV infection. These findings allow us to identify two groups of patients with Hashimoto's thyroiditis: EBER+/LMP1- cases characterising a type I latency or resting EBV infection, whereas EBER+/LMP1+ samples represent a latency type II or III. Type III latent EBV infection is referred to as proliferating or transforming state. Considering the morphological characteristics of
Hashimoto's thyroiditis samples (high percentage of infiltrating lymphocytes, lymphatic follicles formation, fibrosis, etc.) most of the LMP1+ cases showed only a low number of lymphocytes, characteristic for an early stage of autoimmunity. In these cases there was also a more pronounced LMP1 positivity in the follicular epithelium. LMP1 is a viral mimic of CD40, a costimulatory protein found on antigen-presenting cells with the function of an activating receptor of various immune cells, mainly B lymphocytes. Thus, LMP1 signalling to B cells lacks regulatory control, allowing LMP1 to activate $B$ lymphocytes in an abnormal manner that can contribute to the pathogenesis of human B-cell lymphoma and autoimmune disease $[19,20]$.

It is believed that a long-lasting chronic inflammatory irritation in autoimmune states could be the pathogenic basis for development of malignant tumours. More than $90 \%$ of all primary thyroid lymphomas develop in patients with a history of Hashimoto's disease [21]. The majority of these lymphomas are of B cell origin. EBV has the ability to transform normal resting $B$ cells in vitro to proliferating lymphoblasts. This EBVinduced transformation is connected to type III latent infection [17]. Determining the latency type could in these cases have a potential prognostic value separating Hashimoto's disease patients with a higher risk for malignant lymphoma development. The main lymphoma types occurring in patients with Hashimoto's disease are diffuse large B-cell lymphoma (DLBCL) and mucosa-associated lymphoid tissue (MALT) lymphomas [21]. A direct link to EBV infection in these lymphomas has not yet been clearly established. The distinction of a new subtype of DLBCL, EBV-positive DLBCL of the elderly, indicates that at least a subset of these lymphomas is associated with EBV [22].

EBV also plays an etiopathogenic role in several epithelial malignancies, foremost nasopharyngeal carcinoma. Hannigan et al. [23] have demonstrated that the transgenic expression of EBV latent membrane protein 1 induces different changes in epithelial tissue, including not only proliferation, but also production of inflammatory cytokines and chemokines. Accordingly, EBV infection of follicular epithelial cells could contribute to the recruitment of inflammatory cells in autoimmune thyroiditis.

In summary, we demonstrated a high prevalence of EBV infection in cases of Hashimito's thyroiditis (80.7\%) as well as in samples of Graves' disease (62.5\%). The results of the presented study may be partially influenced by the limited amount of the analyzed samples. Nevertheless, the present findings could imply a critical etiopathogenic role of EBV in autoimmune thyroid disease. The initiation of EBV-linked autoimmune thyroiditis could start with changes in the follicular 
epithelium caused by transforming latency type III EBV infection characterised by LMP1 expression. These epithelial changes may also involve the production of inflammatory mediators leading to the recruitment of lymphocytes. The EBV positivity of the infiltrating lymphocytes could be only the presentation of a carrier state, but at least in cases with EBER+/ LMP1+ lymphocytes - transforming latent infection - it could be a negative prognostic marker pointing to a higher risk of primary thyroid lymphoma development.

\section{Acknowledgements}

The project was supported by the Ministry of Health, Slovak Republic under the project 2006/23-UK-02 and by the Slovak Research and Development Agency under the project APVV-0282-11.

\section{References}

1. Davies TF. Infection and autoimmune thyroid disease. J Clin Endocrinol Metab 2008; 93: 674-676.

2. Tomer Y, Davies TF. Infection, thyroid disease, and autoimmunity. Endocr Rev 1993; 14: 107-120.

3. Roizman B. The family herpesviridae: general description, taxonomy, and classification. In: Roizman B, eds. The herpesviruses. Plenum Press, New York 1982: 1-23.

4. Baumforth KR, Young LS, Flavell KJ et al. The Epstein-Barr virus and its association with human cancers. Mol Pathol 1999; 52: 307-322.

5. Glaser SL, Lin RJ, Stewart SL et al. Epstein-Barr virus-associated Hodgkin's disease: epidemiologic characteristics in international data. Int J Cancer 1997; 70: 375-382.

6. Gullo C, Low WK, Teoh G. Association of Epstein-Barr virus with nasopharyngeal carcinoma and current status of development of cancer-derived cell lines. Ann Acad Med Singapore 2008; 37: 769-777.

7. Kelly GL, Rickinson AB. Burkitt lymphoma: revisiting the pathogenesis of a virus-associated malignancy. Hematology Am Soc Hematol Educ Program 2007: 277-284.
8. Handel AE, Williamson AJ, Disanto G et al. An updated meta-analysis of risk of multiple sclerosis following infectious mononucleosis. PLoS One 2010; 5 .

9. Levin LI, Munger KL, O'Reilly EJ et al. Primary infection with the Epstein-Barr virus and risk of multiple sclerosis. Ann Neurol 2010; 67: 824-830.

10. Lunemann JD, Tintore M, Messmer B et al. Elevated Epstein-Barr virusencoded nuclear antigen-1 immune responses predict conversion to multiple sclerosis. Ann Neurol 2010; 67: 159-169.

11. Toussirot E, Roudier J. Epstein-Barr virus in autoimmune diseases. Best Pract Res Clin Rheumatol 2008; 22: 883-896.

12. Desailloud R, Hober D. Viruses and thyroiditis: an update. Virol J 2009; 6: 5.

13. Vrbikova J, Janatkova I, Zamrazil V et al. Epstein-Barr virus serology in patients with autoimmune thyroiditis. Exp Clin Endocrinol Diabetes 1996; 104: 89-92.

14. Baloch ZW, LiVolsi VA. Pathology of thyroid and parathyroid disease. In: Mills SE, eds. Sternberg's diagnostic surgical pathology. Lippincott Williams \& Wilkins, a Wolters Kluver business, Baltimore 2010: 493 -545 .

15. Tozzoli R, Barzilai O, Ram M et al. Infections and autoimmune thyroid diseases: parallel detection of antibodies against pathogens with proteomic technology. Autoimmun Rev 2008; 8: 112-115.

16. Thomas D, Liakos V, Michou V et al. Detection of herpes virus DNA in post-operative thyroid tissue specimens of patients with autoimmune thyroid disease. Exp Clin Endocrinol Diabetes 2008; 116: 35-39.

17. Kasprzak A, Spachacz R, Wachowiak J et al. Epstein-Barr virus (EBV) infection in B-cell non-Hodgkin's lymphomas in children: virus latency and its correlation with CD21 and CD23 molecules. Folia Histochem Cytobiol 2007; 45: 169-179.

18. Tao Q, Robertson KD, Manns A et al. Epstein-Barr virus (EBV) in endemic Burkitt's lymphoma: molecular analysis of primary tumor tissue. Blood 1998; 91: 1373-1381.

19. Peters AL, Stunz LL, Meyerholz DK et al. Latent membrane protein 1 , the EBV-encoded oncogenic mimic of CD40, accelerates autoimmunity in B6.Sle1 mice. J Immunol 2010; 185: 4053-4062.

20. Graham JP, Arcipowski KM, Bishop GA. Differential B-lymphocyte regulation by $C D 40$ and its viral mimic, latent membrane protein 1 . Immunol Rev 2010; 237: 226-248.

21. Watanabe N, Noh JY, Narimatsu $\mathrm{H}$ et al. Clinicopathological features of 171 cases of primary thyroid lymphoma: a long-term study involving 24553 patients with Hashimoto's disease. Br J Haematol 2011; 153: 236-243.

22. Hofscheier A, Ponciano A, Bonzheim I et al. Geographic variation in the prevalence of Epstein-Barr virus-positive diffuse large B-cell lymphoma of the elderly: a comparative analysis of a Mexican and a German population. Mod Pathol 2011; 24: 1046-1054.

23. Hannigan A, Qureshi AM, Nixon C et al. Lymphocyte deficiency limits Epstein-Barr virus latent membrane protein 1 induced chronic inflammation and carcinogenic pathology in vivo. Mol Cancer 2011; 10: 11. 